\title{
Waste Management and Its Effects on Economic Growth: Case Study of Canada
}

\author{
Jaspreet Singh Bhuller and Qiuyan Yuan
}

\begin{abstract}
In recent years, public awareness about solid waste management had been increased due to reason that economic growth has affected with poor waste management practices. According to some studies, most of the waste generated has been disposed without any waste treatment in open dumps and landfills creating unhygienic conditions, affecting public health, environment and economy of a country. This project summarizes the existing knowledge regarding the economic impact of waste management. A case study is added at the end which shows the comparison between provinces of Alberta and British Columbia. It was noted that waste management process produces new jobs and with increase in Gross Domestic Product (GDP), waste generation also increases. Sustainable system is more efficient in overall development of a country and waste diversion is the most preferable method for waste management.
\end{abstract}

Keywords - Solid Waste Management, Economic growth, Gross Domestic Product (GDP), Sustainable, waste diversion.

\section{INTRODUCTION}

Waste can be defined as any material which has been discarded after its primary use or any material which has no real value or faulty in nature can be considered as waste. In OECD (The Organisation for Economic Co-operation and Development) countries, from 1980 to 1997, there was a rapid increase in the generation of municipal solid waste by $40 \%$ (1). In terms of Canada, from 1980 to 1997, percentage of waste generation increased by $17 \%$ and thus results in one of the world's worst performer in this category (2).

In early era, waste was not a big problem because of less population and less industrialization. But with an advancement in technology and rapid increase in industrialization and urbanisation, management of waste generated becomes a great challenge. Also, swift increase in the growth of population in world is a big reason for huge amount of waste generation. Thus, waste management is an important consideration to be taken of.

Waste management is the process of managing the waste from its generation to its disposal. This include steps like collection of waste, transportation of waste, treatment and disposal of waste along with regulations and monitoring of whole process (3). Firstly, waste management focuses on minimizing the harmful effect of waste on human health.

Qiuyan Yuan, Department of Civil Engineering / University of Manitoba Canada.

Jaspreet Singh Bhuller, Department of Civil Engineering / University of Manitoba, Canada
Secondly, waste management supports healthy environment by controlling water pollution, soil pollution and air pollution. Waste management leads to economic development as it ensures the conservative use of resources and provides waste management services. Moreover, main goal of waste management is to improve the economic growth by generating new employment and income sources (4). Both positive and negative impacts of solid waste management are seen on economic growth. More focus should be given on making the whole system sustainable that is system should be environmentally friendly, efficient and socially acceptable. Job employment directly effects the economic growth of a country. More the employment is, more will be the rise in economic growth. In past few years, it has been seen that more the waste generation is, more are the chances of increase in Gross Domestic Product (GDP) (5).

\section{INTEGRATED SOLID WASTE MANAGEMENT}

According to United States Environmental Protection Agency (EPA), Integrated solid waste management (ISWM) is a system which consists of waste reduction, collection, composting, recycling and landfilling. ISWM is a method which focuses on making a sustainable system which is economical, socially acceptable and environmentally friendly for human beings as well as for the environment too (6). ISWM system can be efficient if it consists of different management options such as how to reduce, reuse, recycle and manage the waste. It depends upon the conditions of local community and needs. Best suitable option is then chosen and implemented according to need of the locality

\section{A. Approaches for Integrated Solid Waste Management}

Integrated Solid Waste Management consists of mainly three approaches which are as follows:

- Waste Prevention

- Recycling and Composting

- Disposal (Landfilling and Combustion)

Each of these approaches require some important actions like financing, planning, collection and transportation. Main goal that has to be achieved by effective ISWM system is to prevent environment and to protect human health in most efficient way by searching best option to manage and reduce solid waste (6).

\section{B. Waste Prevention}

Waste prevention is also known as source reduction. Goal of 
this approach is to minimize the waste generation. Source reduction can be done by adopting different steps such as:

- Reusing of materials and products.

- Using fewer packaging materials or using recyclable packaging.

- Avoiding deterioration of food by providing better storage and by reducing food waste.

- Designing durable products that has longer life span.

- Designing of products that would be easily recyclable.

Moreover, more the waste reduction is, less will be the cost used for processing. Thus, this approach helps in improving the economy of a country.

\section{Recycling and Composting}

Recycling is one of the most important phase of Integrated Solid Waste Management system. Recycling is a process in which waste material is collected such as glass, paper, metal etc. and recycled and from that waste material a new material or product is made. It consists of three stages:

- Collection

- Segregation

- Recovering process

In Canada, in 1992, around 4.4 million tons of municipal solid waste (construction and demolition waste, residential waste, industrial, commercial and institutional waste) had been recycled. Composition of material that was recycled consisted of approximately 1.78 million tons of paper, 1.01 million tons of metal, 0.85 million tons of inorganics, 0.39 million tons of organics, 0.24 million tons of glass, 0.07 million tons of plastic, 0.08 million tons of other materials (7). In recycling process, most of the energy is consumed in collection of waste material (approximately above 80\%) in the form of fuel followed by segregation of materials (7). This process put effects on the economic growth of country as well.

On the other hand, composting is the process of converting the organic waste into soil conditioners which can be used to improve the quality of soil and can be used in field of agriculture. All the nutrients which are necessary for a quality soil are present in composting thus helps in providing proper nourishment to the plants.

In Canada, in 1992, approximately 0.413 million tons of compost were diverted which was about $7.01 \%$ of the total waste diverted. Out of 0.413 million tons of diverted compost, 0.315 million tons of compost were diverted using central composting facilities and 0.098 million tons were composted by people of Canada through backyard composting (7).

\section{Disposal (Landfilling and Combustion)}

Combustion of waste is also known as incineration process. Incineration decreases the load of waste on landfill. Any waste product or material which cannot be recycled or composted can send out to incineration plant where the waste material can be burned out in controlled conditions. Thus, it helps in reducing the volume of waste as well as eliminates the risk of hazardous greenhouse gases. Electricity can also be generated through this process because of enormous amount of heat produced (6).

Apart from that, landfilling is the last stage of Integrated Solid Waste Management system which is used for the disposal of waste material which cannot be recycled or cannot be reused. Sanitary landfill is a landfill properly designed, constructed and maintained facility by engineers for disposal of waste material. Energy can also be generated in the form of methane gas under anaerobic conditions through landfills (6).

According to government of Canada, in 1991 there were total of around 10,000 number of landfills in which most of the landfills were in rural areas which were comparatively small in size. In 1992, municipal solid waste that was sent to landfill was approximately 17.52 million tons. Composition of this waste was 6.1 million tons of paper, 5.5 million tons of organics in the form of kitchen waste and yard waste, 1.6 million tons of plastics, 1.4 million tons of metal, 1.8 million tons of other waste material, 0.68 million tons of glass, 0.47 million tons of inorganics. Thus, approximately 1.76 kilogram of municipal solid waste per capita were sent to the landfill each day (7).

\section{ECONOMIC GROWTH AND WASTE MANAGEMENT}

The current world population is about 6 billion and every year the population grows by 78 million, causing high consumption of majority of the natural capital (8). This inturns generate more waste and has already become a major issue all over the world, leading to huge consumption of resources and high levels of pollutants. Every waste has a cost which is considered as the direct loss, and it is about $10-30 \%$ of the annual turnover depending to the type of firm. There are number of economic benefits associated with the waste recycling, as the material recycling gives about ten-fold more economic benefits as compared to energy recovery. Circular economy is an industrial system, which is regenerative or restorative by design. This promotes the uses of renewable energy and eliminates the end-of-life theory by restoration. Circular economy is a trillion-dollar opportunity by which the innovation and economic growth can be achieved.

In general, private contractors and public agency are held responsible to collect waste and considered as the primary government concern in developed nations. The total waste generated are not collected in most of the cities and usually a portion of the gathered waste receives proper treatment or disposal. This improper gathering and treatment or disposal of waste pose risk to the health of living beings and destroys the environment, and these waste/pollutants are mainly considered as the source of air, water and soil pollution. Thomas-Hope (9), Schübeler (10) and Bartone (11) studied the expenditure of the municipal revenues on the waste management, and they found that the developing countries usually spent about 20$40 \%$ revenues which is still not enough to have an upper hand on the problem. It has been forecasted that in 2025 the expenditure on the waste management is going to be twice as compared to the expenditure in 1999 (12).

The solid waste management considered to have both 
positive and negative impact on the economic growth. There also exist a strong link between environment and economy. Waste areas should contribute towards the economic sustainability, rather than only focusing on the negative environmental effects. This could be achieved by creating more jobs by opening enterprises and reducing waste disposal cost by lowering the amount of waste generated. Funds and investments are necessary in the waste sector such that the waste management could have positive impact on the economy of the nation. As per International Solid Waste Association, this cost varies around $3 \%$ to $15 \%$ (city's budget) or $0.1 \%$ to $0.7 \%$ (per capita GDP) for providing waste management services (5). However, if there does not exist ways to manage waste effectively the economy could be negatively affected. European Union put a step forward with an objective to become a "recycling society" by promoting greener economy, which means organized and better security of supplies (13). A growth in the GDP (Gross Domestic Product) was observed in many nations alongside with the rise in the amount of the waste generated in past few years. Waste management helps to reduce the harmful impacts related with waste and presents an opportunity towards sustainable future.

Solid waste management (SWM) is considered to be the greatest challenge worldwide, as it not only affects environment but also hinders the growth of the nation and its progress towards sustainable development. The conceptual framework was prepared to achieve sustainable development with the growing economy and by implementing proper SWM strategies. It can be concluded that with the growing economy and population large amount of solid wastes is generated.

"Decoupling" is a vital concept as the increase in the global population and economic development will increase resource consumption. In order to move towards sustainable society, the myth that the resource consumption comes with the economic growth should be tackled, and this could be achieved through waste management. The sustainable development can be achieved even by lowering the resource consumption by following the conceptual framework.

SWM also have a major impact on the residential property values and most vital sector creating employment is recycling (14). For instance, Albania put a step forward by building 12 regional landfills that will cause profit on large scale, according to the National Plan of Solid Waste Management 2010-2025. By implementing this plan, the municipalities will co-operate together to manage the waste which will reduce individual cost and provide higher standards. It was well calculated that investing in these landfills will lead to new jobs, therefore enhance the welfare of the society with increased consumption which in-turn have a positive impact on the economy.

\section{LEGISLATION OF SOLID WASTE MANAGEMENT IN CANADA}

In Canada, all the regulations and rules are set up by the provincial governments within their jurisdiction for safe disposal of waste materials so that it would not affect the environment in harmful manner (15). However, it depends upon local municipalities that which approach they should adopt, and which approach would be economic for their city or province (16). In some provinces of Canada, participation of private sectors is more common as according to the residents they are more efficient, effective and economical (17). Landfill taxes and funds provided by government are some successful ways for diversion of waste from landfills (2). Below Table 1 gives information of provinces or territories of Canada about legislations related to solid waste management.

\begin{tabular}{l} 
TABLE I. SOLID WASTE MANAGEMENT RELATED LEGISLATION IN CANADA \\
\begin{tabular}{|l|l|}
\hline \multicolumn{1}{|c|}{$\begin{array}{c}\text { PROVINCE or } \\
\text { TERRITORY }\end{array}$} & \multicolumn{1}{c|}{ LEGISLATION } \\
\hline Alberta (Alta.) & $\begin{array}{l}\text { Environmental Protection and } \\
\text { Enhancement Act }\end{array}$ \\
\hline $\begin{array}{l}\text { British Columbia } \\
\text { (B.C.) }\end{array}$ & $\begin{array}{l}\text { Waste Management Act, Environmental } \\
\text { Management Act }\end{array}$ \\
\hline Manitoba (MB) & The Waste Reduction and Prevention Act \\
\hline New Brunswick (N.B.) & Clean Environment Act \\
\hline New Foundland (N.L.) & $\begin{array}{l}\text { Waste Management Regulation (2003) } \\
\text { under the Environmental Protection Act }\end{array}$ \\
\hline Nova Scotia (N.S.) & $\begin{array}{l}\text { Environment Act; Solid Waste Resource } \\
\text { Management Regulations }\end{array}$ \\
\hline Ontario (Ont.) & $\begin{array}{l}\text { Waste Diversion Act; Environmental } \\
\text { Assessment Act }\end{array}$ \\
\hline $\begin{array}{l}\text { Prince Edward Island } \\
\text { (P.E.I.) }\end{array}$ & Environment Protection Act \\
\hline Quebec (Que.) & Environment Quality Act \\
\hline Saskatchewan (Sask.) & $\begin{array}{l}\text { Environmental Management and protection } \\
\text { Act; The Municipal Refuse Management } \\
\text { Regulation }\end{array}$ \\
\hline $\begin{array}{l}\text { North West Territory } \\
\text { (N.W.T.) }\end{array}$ & Waste Reduction and Recovery Act \\
\hline Nunavut (Nun.) & Environment Protection Act (Nunavut) \\
\hline Yukon (Yuk.) & $\begin{array}{l}\text { Solid waste regulation under the } \\
\text { Environment Act }\end{array}$ \\
\hline Sources: (17, 18) &
\end{tabular} \\
\hline
\end{tabular}

Sources: $(17,18)$

\section{CASE StUdy OF CANADA}

\section{A. Waste generated in Alberta and British Columbia}

Among world, Canada generates more solid waste material as compared to other countries. Approximately 32,947,000 tonnes of solid waste were generated by Canada in 2010 which was $20.9 \%$ greater than the generation of solid waste in 1996 (approximately 26,078,000 tonnes). This shows that in between these fourteen years, there was an alarming increase in the generation of solid waste (6).

Around $26.6 \%$ of Canada's total waste was generated by Alberta and British Columbia which was approximately $8,745,000$ tonnes in 2010. In terms of per capita waste generation, British Columbia have high waste generation rate as compared to Alberta which were 3.23 and 2.47 $\mathrm{kg}$ /capita・day respectively (6). Table 2 shows the comparison between the provinces Alberta and British Columbia. 
TABle II. Features of AlBerta AND BRITISH Columbia (DATA IN 2008)

\begin{tabular}{|l|c|c|}
\hline & Alberta & $\begin{array}{c}\text { British } \\
\text { Columbia }\end{array}$ \\
\hline Total land area, sq. km & 661,848 & 944,735 \\
\hline Proportion of Canada, \% & 6.6 & 9.5 \\
\hline Population & $3,433,150$ & $4,384,310$ \\
\hline Population Density, population/km² & 5.19 & 4.64 \\
\hline $\begin{array}{l}\text { Gross Domestic Product (GDP) per } \\
\text { Capita, \$/person }\end{array}$ & 84,198 & 42,099 \\
\hline Waste Diversion Rate, \% & 14.9 & 34.9 \\
\hline
\end{tabular}

Source: Asha et al., 2015

In Alberta, residential waste was generated about 620,000 tonnes which accumulates $20.6 \%$ of total waste whereas nonresidential waste was generated about 2,387,000 tonnes which accumulates $79.4 \%$ of total waste in 1996. In year 2010, residential waste was generated about 1,303,000 which accumulates $28.1 \%$ of total waste whereas non-residential waste was generated about 3,327,000 tonnes which accumulates $71.9 \%$ of total waste. On the other hand, in terms of British Columbia, residential waste was generated about 867,000 tonnes which accumulates $30.5 \%$ of total waste whereas non-residential waste was generated about 1,974,000 tonnes which accumulates $69.5 \%$ of total waste in 1996. In year 2010, residential waste was generated about 1,629,000 which accumulates $43.9 \%$ of total waste whereas nonresidential waste was generated about 2,084,000 tonnes which accumulates $56.1 \%$ of total waste (6).

\section{B. Waste management in Alberta and British Columbia}

Waste diversion means diverting the waste material going to landfill for disposal. Waste Diversion is the process of averting and avoiding the generated waste by means of source reduction, reuse and recycle. Waste diversion is main concept in both Alberta and British Columbia as it reduces impact of greenhouse gases on atmosphere, reduce financial cost on waste treatment, provides social benefits, conserve energy by reducing usage of fossil fuels, reduce the disposal costs, reduces burden on treatment facilities as well as on landfill. Waste that has been generated in the society undergoes different activities. Some of the waste goes directly to landfill, some goes to composting facility whereas some goes to combustion treatment units, while some waste has been recycled through material recovery facilities (MRF).

Figure 1. shows the waste diversion between British Columbia and Alberta from period 1996 to 2010. British Columbia is performing better than Alberta in this approach. Alberta has lower diversion rate than average diversion rate of Canada whereas British Columbia has opposite results than Alberta throughout the whole period except year 1996. Mean diversion rates for Alberta and British Columbia were 14.9\% and $34.9 \%$ respectively. There are some factors too that affects the impact of diversion rate. Some common factors are workforce and expenditure $(19,20)$.

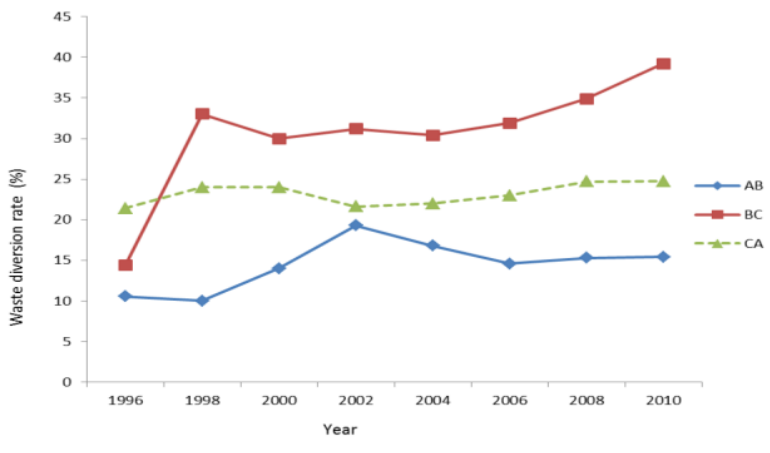

Fig. 1 Waste diversion rate in Alberta and British Columbia (6)

\section{Effect of waste management on economic growth of Alberta and British Columbia}

Selected study period is between 1996 to 2010 because of the availability of data. For the proper operation of solid waste management system both Alberta and British Columbia spent almost equal amount of money except 2008 and 2010. Figure 2. shows the relationship in private sectors. Almost half of the money was spent more by Alberta on private sectors for diversion of waste. From 2006 to 2008, there was a rapid increase in operating expenditures per capita of Alberta. In Alberta, waste diversion rate cannot be increased by increasing the amount of expenditures. Operating revenues in private sectors for Alberta and British Columbia were \$284.84 and $\$ 178.04$ respectively (6).

On the other hand, current expenditure per capita for government sectors were more in British Columbia throughout the study period except 2010 where Alberta has spent higher income per capita as shown in figure 3. Although more money is spent by Alberta in 2010 but still it has lower diversion rates as compared to British Columbia. Moreover, it has been noted that private sectors spent more money than government sectors for both the provinces. In the epilogue, both private sectors and government sectors spent money for diversion of waste, but it does not affect the diversion rates up to great extent because of the reasons of awareness, rules and regulations etc. Operating revenues in government sectors for Alberta and British Columbia were $\$ 117.42$ and $\$ 96.80$ respectively (6).

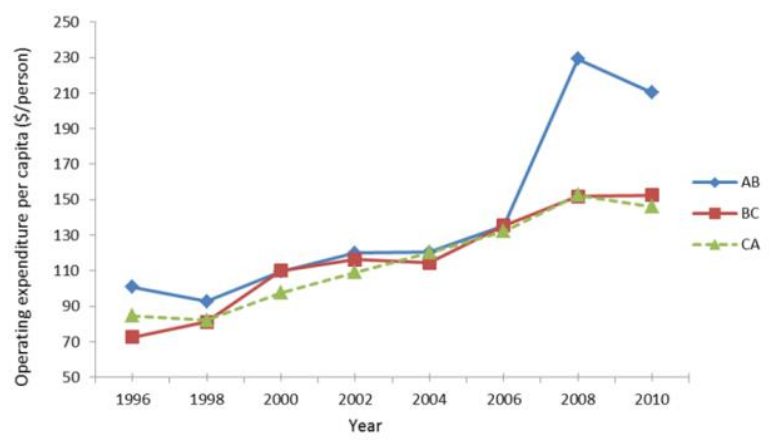

Figure 2. Operating expenditure per capita in private sectors in Alberta and British Columbia (6) 


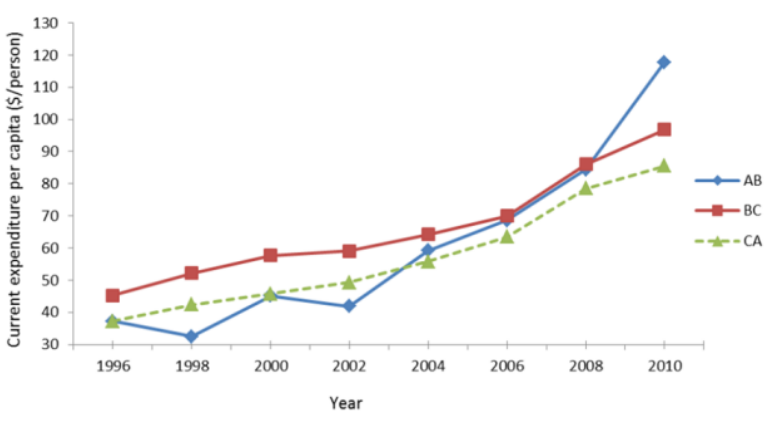

Figure 3. Current expenditure per capita in Government sector in Alberta and British Columbia (6)

\section{GOVERNMENT SECTOR EXPENDITURES AS BY ECONOMIC PERSPECTIVE}

Limited data is available about economic prospective of the country, available data up to year 2010 is given in table 3. In Canada, Total number of employees (summation of full time employees and part time employees) was increasing as the waste generation increasing throughout the period which relates to some increase in economic growth of country. Values for revenues and expenditures are given. $(x)$ sign refers to the confidential data which is not given by the federal government as well as the provincial governments. Collection and transportation cost are much higher as compared to other activities. Data about operating revenues, expenditures and capital expenditures is given in table 3. Below is the comparison between provinces of Alberta and British Columbia.

\begin{tabular}{|c|c|c|c|}
\hline $\begin{array}{l}\text { Local government } \\
\text { characteristics }\end{array}$ & Canada & Alberta & $\begin{array}{c}\text { British } \\
\text { Columbia }\end{array}$ \\
\hline Total employees & 7816 & 1,637 & 924 \\
\hline Full time employees & 6337 & 1,388 & 696 \\
\hline Part time employees & 1479 & 249 & 228 \\
\hline Operating revenues & $2,387,457$ & 378,893 & 441,880 \\
\hline All current expenditures & $2,916,928$ & 416,147 & 438,479 \\
\hline $\begin{array}{l}\text { Collection and } \\
\text { transportation, current } \\
\text { expenditures }\end{array}$ & $1,233,696$ & 153,497 & 139,427 \\
\hline $\begin{array}{l}\text { Tipping fees, current } \\
\text { expenditures }\end{array}$ & 424,773 & 81,535 & 46,317 \\
\hline $\begin{array}{l}\text { Operation of disposal } \\
\text { facilities, current } \\
\text { expenditures }\end{array}$ & 516,991 & 54,046 & 126,234 \\
\hline $\begin{array}{l}\text { Operation of transfer } \\
\text { stations, current } \\
\text { expenditures }\end{array}$ & 145,960 & $x$ & 52,027 \\
\hline $\begin{array}{l}\text { Operation of recycling } \\
\text { facilities, current } \\
\text { expenditures }\end{array}$ & 157,248 & 26,087 & 13,211 \\
\hline $\begin{array}{l}\text { Operation of organics } \\
\text { processing facilities, current } \\
\text { expenditures }\end{array}$ & 74,525 & $x$ & 5,568 \\
\hline $\begin{array}{l}\text { Contributions to landfills } \\
\text { post closure and } \\
\text { maintenance fund, current } \\
\text { expenditures }\end{array}$ & 93,171 & 37,131 & 16,388 \\
\hline Other current expenditures & 270,564 & 33,128 & 39,306 \\
\hline Capital expenditures & 537,114 & 110,378 & 127,209 \\
\hline
\end{tabular}

Source: (21)

\section{CONCLUSIONS}

A comprehensive review is presented with the aim of effect of economic growth on waste management. The following findings are reported:

- Waste management helps in providing new jobs that helps the local families.

- Green energy has been produced from waste management which reduces burden on renewable resources.

- Waste management helps in reducing individual cost and provide higher standards, thus shows positive impact on economy.

- British Columbia is more superior than Alberta in terms of diverting the waste generated.

- Industrialised area is greater in Alberta, so proper waste management techniques will tend to generate more jobs which would increase the economic growth of Alberta.

- Circular economy is a possible way to achieve better economic growth.

- With increase in GDP, waste generation also increases

\section{REFERENCES}

[1] King, Andrew M., et al. "Reducing waste: repair, recondition, remanufacture or recycle?" Sustainable Development 14.4 (2006): 257 267.

https://doi.org/10.1002/sd.271

[2] Bonam, Rathan Kumar. "Understanding waste from a climate change perspective: municipal solid waste management in Canada." (2009).

[3] United Nations Statistics Division - Environment Statistics. unstats.un.org. Retrieved 3 March 2017.

[4] B. Smith, "An approach to graphs of linear forms (Unpublished work style)," unpublished.

[5] International Solid Waste Association, June 2013.

[6] Asha, Aklima Zerin. Analysis and Comparison of Solid Waste Management Systems and Diversion Practicies in Alberta and British Columbia. Diss. Faculty of Graduate Studies and Research, University of Regina, 2015.

[7] Sawell, S. E., S. A. Hetherington, and A. J. Chandler. "An overview of municipal solid waste management in Canada." Waste management 16.5-6 (1996). https://doi.org/10.1016/S0956-053X(97)85024-6

[8] Kanbar, Nancy. "An Environmental economic approach to assess the sustainability of managing a protected area in Lebanonll." George Mason University, Beirut (2003).

[9] Thomas-Hope, Elizabeth M., ed. Solid waste management: critical issues for developing countries. Canoe Press, 1998.

[10] Sawell, S. E., S. A. Hetherington, and A. J. Chandler. "An overview of municipal solid waste management in Canada." Waste management 16.5-6 (1996). https://doi.org/10.1016/S0956-053X(97)85024-6

[11] Bartone, Carl. "Strategies for improving municipal solid waste management: lessons from world bank lending and CWG activities." Workshop on planning for sustainable and integrated solid waste management, Manila. 2000.

[12] World Bank (1999), - What a Waste: Solid Waste Management in Asiall, Urban Development Sector Unit, East Asia and Pacific Division, Working Paper SeriesNo.1.

[13] European Council, June 2010, http://ec.europa.eu/eu2020/pdf/ council_conclusion_17_june_en.pdf

[14] Ogedengbe, P. S., and J. B. Oyedele. "Effect of waste management on Property values in Ibadan, Nigeria." Journal of land use and development studies 2.1 (2006): 71-78. 
[15] Environment Canada (2013a). Managing and Reducing Wastes. Government of Canada. Retrieved on 15 May 2014 from http://www.ec.gc.ca/gdd-mw/.

[16] Oyegunle, Ahmed. "Solid waste management practices in two northern Manitoba first nations communities: community perspectives on the issues and solutions." (2016).

[17] Statistics Canada (2005). Human Activities and the Environment. Catalogue No. 16-201-XiE. Retrieved on 07 June, 2014 from http://www.statcan.gc.ca/pub/16-201-x/16-201-x2005000-eng.pdf

[18] Hickey, Gordon M., Nicolas Brunet, and Nadège Allan. "A Constant Comparison of the Environmental Assessment Legislation in Canada." Journal of Environmental Policy \& Planning 12.3 (2010): 315-329. https://doi.org/10.1080/1523908X.2010.509470

[19] Aziz, Shuokr Qarani, et al. "Appraisal of domestic solid waste generation, components, and the feasibility of recycling in Erbil, Iraq." Waste Management \& Research 29.8 (2011): 880-887. https://doi.org/10.1080/1523908X.2010.509470

[20] Sujauddin, Mohammad, S. M. S. Huda, and ATM Rafiqul Hoque. "Household solid waste characteristics and management in Chittagong, Bangladesh." Waste management28.9 (2008): 1688-1695. https://doi.org/10.1080/1523908X.2010.509470

[21] Statistics Canada. Table 38-10-0036-01 Local government characteristics of the waste management industry. 